\title{
Impact of the subsidy on the electric rate in the use of renewable energy for net zero housing in Mexicali, Mexico
}

\author{
R. Gallegos ${ }^{1}$, E. Tapia ${ }^{1} \&$ S. Romero ${ }^{2}$ \\ ${ }^{1}$ Faculty of Architecture and Design, Autonomous University of Baja California, \\ Mexico \\ ${ }^{2}$ Institute of Engineering, Autonomous University of Baja California, Mexico
}

\begin{abstract}
The city of Mexicali, located in the Northwest of Mexico, has a hot extreme climate, with maximum temperatures of up to $48^{\circ} \mathrm{C}$, so the use of air conditioning systems is a necessity for the realization of human activities. But the intensive use of these systems brings with it high consumptions of electric energy, so billing is very expensive for the majority of the population. For this reason, the city has a subsidy by the State in the electricity tariff, allowing users to allocate less of their income to pay for the service. In this context, the State agency that produces and distributes electric power has developed mechanisms to allow domestic cogeneration using photovoltaic systems of up to $3 \mathrm{~kW}$. This paper describes the design and simulation of a net zero house interconnected to the grid for users of middle class. The first task was to reduce energy requirements for air conditioning through the use of appropriate materials and construction systems, use of natural lighting, changing the type of lighting and thermal insulation. Subsequently the photovoltaic system is designed and an estimate of the recovery time of the investment is done. The results show that with the levels of subsidy rate, the net zero housing scheme is not able to recover the investment in the life time of the project. If the rate were not subsidized, investment is recovered in the fourth part of the life time; approximately five years. It is concluded that for this sector of the population the State could allocate the amount of the subsidy for those five years to finance PV systems and eliminate the subsidy, the amount of which may be used for social works. An additional benefit would be the incentive to the use of renewable energy in the country.
\end{abstract}

Keywords: net zero housing, renewable energy, domestic cogeneration. 


\section{Introduction}

The city of Mexicali, capital of the State of Baja California, Mexico, is located in the Northwest of the country, bordering the United States of North America. It is located in the Altar desert, which also covers the States of Sonora in Mexico, and part of California and Arizona in the United States. Its climate is classified, according to Köppen, as Bwh. The maximum average temperatures in the warm season range from 37 to $46^{\circ} \mathrm{C}$, with historic records of up to $52^{\circ} \mathrm{C}$. The solar energy received at the same time range from 4600 to $8200 \mathrm{Wh} / \mathrm{m}^{2}$ as a daily average. Due to these climatic conditions, air conditioning becomes a necessity for the realization of human activities. Formerly, evaporative cooling was preferably used, but from the decade of 1970 vapor compression systems have been extensively used. Vapor compression systems consume more electricity than evaporative cooling, so the billing of electricity represents a significant proportion of the income of the users. That is why the State has subsidized the domestic electricity tariff for locations in which the maximum ambient temperature is superior to $33^{\circ} \mathrm{C}$, through the so-called tariff $1 \mathrm{~F}$ [1]. This tariff varies from month to month, and the subsidized period is from May to October. Table 1 shows the $1 \mathrm{~F}$ rate for the year 2013, with costs expressed in cents of US dollar, at the exchange rate of January 2013.

Table 1: Tariff $1 \mathrm{~F}$ for 2013.

OFF-SUBSIDY
\begin{tabular}{|l|r|r|r|r|r|r|}
\hline Consumption kWh & \multicolumn{1}{l|}{ JAN } & \multicolumn{1}{l|}{ FEB } & \multicolumn{1}{c|}{ MAR } & \multicolumn{1}{c|}{ APR } & NOV & DEC \\
\hline $0-75$ & 6.17 & 6.19 & 6.20 & 6.22 & 6.39 & 6.41 \\
\hline $75-200$ & 7.54 & 7.56 & 7.59 & 7.61 & 7.78 & 7.80 \\
\hline Exceeding & 22.02 & 22.10 & 22.17 & 22.24 & 22.76 & 22.83 \\
\hline
\end{tabular}

\begin{tabular}{|l|r|r|r|r|r|r|}
\hline SUBSIDY \\
\hline Consumption kWh & \multicolumn{1}{|c|}{ MAY } & \multicolumn{1}{l|}{ JUN } & \multicolumn{1}{l|}{ JUL } & \multicolumn{1}{c|}{ AUG } & \multicolumn{1}{l|}{ SEP } & OCT \\
\hline $0-300$ & 4.63 & 4.64 & 4.66 & 4.67 & 4.69 & 4.71 \\
\hline $300-1200$ & 5.84 & 5.85 & 5.87 & 5.89 & 5.90 & 5.92 \\
\hline $1200-2500$ & 14.04 & 14.09 & 14.14 & 14.19 & 14.24 & 14.28 \\
\hline Exceeding & 22.32 & 22.39 & 22.46 & 22.54 & 22.61 & 22.68 \\
\hline
\end{tabular}

A minimum charge equivalent to $25 \mathrm{kWh}$ is applied.

The magnitude of the subsidy can be appreciated when one considers a consumption of $201 \mathrm{kWh}$ : in off subsidy period would be charged on average at $\$ 14.47$ USD while in period of subsidy, the billing would be $\$ 9.38$ USD on average. As for the high consumption rates of the warm season, a consumption of $2501 \mathrm{kWh}$ would respectively be billed at \$528.61 and \$251.24 USD, 
i.e. there is a $54 \%$ subsidy. It is seen that the State allocates resources to the subsidy that could be spent on the promotion of alternative sources of energy in housing, taking advantage of high levels of solar radiation received.

\section{The State's actions to reduce consumption and promote renewable energy sources}

High consumption of electrical energy in the warm season, causes operational problems in the producing plants, run by the state-owned Federal Commission for Electricity (CFE), and generates costs to the State because of the subsidy.

\subsection{Programs to reduce consumption}

A first approach to the solution of this problem was to encourage users to reduce their consumption of electricity, through the promotion of thermal insulation of the houses, a program called FIPATERM, which was created in 1990 by the federal Government to provide funding for the installation of thermal insulation in the residential sector, initially in Baja California. FIPATERM showed to be so successful that currently it operates in fifteen states of the country. A second step was to promote the acquisition of air conditioning, refrigerators and lighting systems of higher efficiency, using the program ASI. Both the program FIPATERM and ASI make loans with a term of three years charged through electricity bills.

\subsection{Interconnection contracts}

Until the year of 2007, the State did not allow individuals to generate electric energy even for self-consumption. From that year on, interconnection contracts were established. These contracts allow users to generate energy to be delivered to the net and be taken into their account as bonus turnover. For the residential sector, the applicable agreement is the contract of interconnection with renewable energy, or small scale cogeneration system (CIFER-PE). CIFER-PE establishes that the maximum installed capacity cannot exceed $10 \mathrm{~kW}$ for users in residential rates. This type of contract does not allow the carrying of power to other centers of consumption. The contract between the generator and the CFE has an indefinite term and does not require a special permit. The agreement establishes the net metering between the electric power delivered by the supplier to the generator and electric power delivered by the generator to the supplier. The net metering consists of a bi-directional meter, which records both the amount of electrical energy supplied to the network by the generator, and that given to the generator. The main feature of this electrical energy compensation scheme is that the supplier calculates the difference between these two amounts of energy .If the generator delivers more power than consumed, it is saved as a credit in favor and can be compensated each month, within a maximum period of 12 months, at the end of which, a new account is started. If the difference between the power supplied and generated is zero, then the generator will only 
pay the minimum charge established in the normal supply contract. The investment for the construction of facilities and equipment required for the generation of electricity through renewable energy sources, as well as the bi-directional meter, will be provided by the generator. Also, the generator will take care of any modifications that may be necessary for interconnection, same that will be carried out under the supervision of the CFE.

\section{Net zero housing}

Since the institution of interconnection agreements, domestic cogeneration of electricity is possible thus aiding in its evolution towards the ideal of net zero housing. A Net Zero Energy Building (NZEB) is a residential or commercial building with reduced energy needs, accomplished through greater efficiency, in such a way that the balance of energy needs could be supplied by renewable technologies [2]. For Voss et al., a NZEB is an energy-efficient building that, in combination with public electricity infrastructure network, complies with the annual total primary energy demand, determined from a monthly balance, where credit of primary energy by the surplus of electricity delivered to the network is accounted [3]. The electricity generated at the site, is mainly used to meet the energy demand of the building in question. Seen in these terms, they do not need fossil fuels for heating, cooling, lighting or other uses, although sometimes it might be necessary to take some power from the grid. Sartori et al. [4] mention that a NZEB is one with a reduced power demand that can be compensated by equivalent electric power on-site from renewable generation.

\subsection{Case study design}

For the case of study a dwell was designed for a user of the middle-upper class, with the goals of reducing energy for air conditioning requirements, optimizing the use of spaces and including the integration of photovoltaic systems since the design. The premise has a surface of $300 \mathrm{~m}^{2}$ and is located in the urban area of the city of Mexicali. The house was designed for a family of four members.

\subsubsection{Identification of requirements}

In order to determine energy needs as well as spatial and functional requirements, a survey was conducted and applied to each of the members of the family. Needs and requirements were identified based on the conditions of the house occupied by the family, and the results were taken as a reference to identify wishes, needs and requirements. The different types and frequency of activities carried out in each space and by each person were determined in order to assign the internal heat gain due to occupation. The other components of the internal thermal load were determined using the results of the survey, which also included the patterns of use of electric appliances and lighting. 


\subsubsection{House design}

The shape of the house is a rectangular prism developed into two levels. The prism is oriented with his long side facing South, in such a way that the longitudinal axis of the house is located along the East-West direction. This shape and orientation were chosen to take advantage of the solar incidence during the cold period. On the other hand, the East and West side of the prism was shaped with reduced proportions, to lower the incidence of direct sunlight on the building in hours with higher temperatures during warm period. The tilted roof was developed on the East-West axis, generating a collector area to allocate the photovoltaic system (PVS). The supporting elements of the PVS stand higher than the built elements in the neighborhood in order to allowed sunlight.

\subsubsection{Reduction of energy requirements}

According to Docherty and Szokolay [5], for Mexicali the most suitable passive technique is the use of thermal mass in summer, in combination with natural ventilation, while in the cold period, it is the thermal mass with direct solar heating. It was decided to have a combination of materials to create a wall of $0.30 \mathrm{~m}$ thick in the envelope of the conditioned areas. Assemblies of materials for every constructive element of the proposed house envelope are shown in table 2 .

On the ground floor, North, West and South facing walls, are constructed according to configuration number 1, in order to protect these, while in the East orientation, the wall chosen was number 3, because spaces in such orientation are unconditioned (laundry and service room) and are shaded from the early hours of the morning. Such spaces are devised as a thermal buffer for the conditioned spaces.

Table 2: Construction assemblies for the envelope.

\begin{tabular}{|l|l|l|l|l|}
\hline & Element & Materials & $\begin{array}{l}\text { Thermal } \\
\text { Resistance } \\
\mathrm{m}^{2} \mathrm{C} / \mathrm{W}\end{array}$ & $\begin{array}{l}\mathrm{R} \\
\text { Value }\end{array}$ \\
\hline 1 & $\begin{array}{l}\text { Apparent } \\
\text { Wall }\end{array}$ & $\begin{array}{l}\text { Brick + EPS + Concrete Block + Gypsum } \\
\text { Plaster }\end{array}$ & 1.60 & 9.07 \\
\hline 2 & $\begin{array}{l}\text { Plastered } \\
\text { Wall }\end{array}$ & $\begin{array}{l}\text { Mortar + Brick + EPS +Concrete block + } \\
\text { Gypsum Plaster }\end{array}$ & 1.61 & 9.14 \\
\hline 3 & Block Wall & Mortar + Concrete Block +Gypsum Plaster & 0.20 & 1.16 \\
\hline 4 & Gable Roof & Asphalt Roll + Wood Singles & 0.18 & 1.05 \\
\hline 5 & Plafond & Gypsum Board + Cellulose Fiber & 6.78 & 38.51 \\
\hline 6 & Flat Roof & Asphalt Roll + Concrete & 0.12 & 0.66 \\
\hline 7 & Doors & Birch Wood & 0.15 & 0.85 \\
\hline 8 & Windows & Single Glass 3 mm Clear & & \\
\hline
\end{tabular}

Upstairs, the bedrooms, where the most of artificial air-conditioning units are located, all walls are type 2 , in order to protect the spaces against high temperatures in the warm period, and on the other hand, in the cold period to keep the heat of the interior spaces. A gable roof was considered, with an internal 
air chamber, and a very thick layer of insulation in contact with the ceiling, corresponding to assembly number 5 , the one with the highest thermal resistance, since the house receives direct solar radiation practically most of the day in the warm period, however, in the cold period, the insulating layer keeps the heat in the interior spaces. To take advantage of the natural ventilation, windows in the South and North facade are proposed, in the ground floor as well as the upper story. Location of windows in the South facade was preferred, in order to take advantage of the incidence of direct solar radiation and increase heat gains during the cold period. In the West facade, the use of windows was completely avoided, since in the warm period, from noon and until the sundown, the combination of high temperatures and direct sunlight, increases heat gain; while in winter, the Sun completes its travel to the Southwest, and that facade would not be useful to heat the house trough windows. To keep the South facade exposed to solar radiation in the cold period and in shade most of the warm period, pergolas attached to the walls of the first and second level were designed, to provide shade from May to October. From April to October shading of 80 to $100 \%$ was achieved on the South surface of both levels, while in the cold period, in December and January, a sunlit area of up to $90 \%$ can be present. No shading devices were proposed on West and East facades, due the shading cast by adjacent buildings and vegetation. On the North surface a side-fin was implemented in order to block direct sunlight on the early and late hours of summer.

To reduce power consumption by artificial lighting, compact fluorescent bulb lights were proposed, $23 \mathrm{~W}$ for bedrooms and common spaces and $18 \mathrm{~W}$ for bathrooms, service rooms and outdoor spaces. As a special case, two $17 \mathrm{~W}$ tubular fluorescent bulbs will be used in the kitchen and another pair in the garage, in order to obtain highest rates of lighting.

\subsection{Simulation and system sizing}

Once defined the thermal reduction strategies, a simulation was run using Energy Plus V8.1, for a whole year using a Typical Meteorological Year file developed for Mexicali. The simulation results allowed to determinate the maximum thermal load for each of the conditioned spaces as follows:

- $\quad$ Thermal Zone 1 (Kitchen, dining room, TV room and bathroom ): $798.86 \mathrm{~W}$

- Thermal Zone 2 (Bedroom 1): 1,102.16 W

- Thermal Zone 3 (Bedroom 2): $327.44 \mathrm{~W}$

- $\quad$ Thermal Zone 4 (Bedroom 3): $397.93 \mathrm{~W}$

A cooling power of 1 refrigeration Ton $(3,517 \mathrm{~W})$ was assigned to each zone, and due to the different occupancy patterns, split equipment was considered with a seasonal energy efficiency rating of 13 , the highest found in the market at that moment.

Knowing the energy needed for air conditioning, lighting and appliance equipment, a photovoltaic system is proposed to provide the total energy demand and other simulation was run to determine the generation of energy. The system 
proposed for the NZEB housing according to annual energy demand, is of 3,300 Wp, consisting of 11 photovoltaic modules, placed on a sloping facing South, at an angle of $32^{\circ}$. The cells are monocrystalline of $300 \mathrm{~W}$ nominal power with efficiency of $15.3 \%$ and useful life of 25 years. The total annual power generation is $6515.36 \mathrm{kWh}$, with a minimum in December of $453.16 \mathrm{kWh}$ and a maximum in April of $630.44 \mathrm{kWh}$.

\section{Economic analysis}

To evaluate the economic feasibility of the NZEB, it was necessary to develop a reference base case, to establish an initial investment with respect to which the proposed NZEB would be compared. The base case has been set respecting geometry, location, orientation, solar control devices, household appliances, ceiling fans and artificial lighting devices, as well as usage patterns specified in the NZEB; the difference is basically in components of the envelope and the efficiency of the artificial air conditioning equipment. The base case meets with the Mexican Official Standard NOM-020-ENER-2011 Energy efficiency in buildings, envelope of buildings for residential use [6]. The proposed air conditioning appliances have a 10 SEER efficiency and comply with the official standards of energy efficiency in air conditioners.

\subsection{Energy costs and payback time}

From a simulation carried out in Energy Plus 7.2, under the same assumptions of simulation to the NZEB, electrical energy consumption estimates for the base case and NZEB, as well as the costs according to the rate $1 \mathrm{~F}$, subsidized and not subsidized (table 3).

Table 3: Monthly consumption and cost of electricity for the base case.

\begin{tabular}{|l|r|r|r|}
\hline & \multirow{2}{*}{$\begin{array}{c}\text { Consumption } \\
\text { kWh }\end{array}$} & \multicolumn{2}{|c|}{ Cost (USD) } \\
\cline { 3 - 4 } & 232.23 & 20.81 & $\begin{array}{c}\text { Subsidized } \\
\text { Subsidized }\end{array}$ \\
\hline Jan & 209.76 & 15.99 & 74.52 \\
\hline Feb & 232.23 & 20.94 & 111.21 \\
\hline Mar & 224.74 & 19.37 & 117.35 \\
\hline Apr & 746.70 & 39.31 & 203.03 \\
\hline May & 921.84 & 49.52 & 349.76 \\
\hline Jun & 1195.37 & 65.47 & 411.89 \\
\hline Jul & 1159.41 & 63.58 & 394.41 \\
\hline Aug & 919.51 & 49.83 & 324.24 \\
\hline Sep & 679.85 & 36.02 & 249.08 \\
\hline Oct & 223.94 & 19.65 & 122.79 \\
\hline Nov & 231.40 & 21.39 & 127.48 \\
\hline Dec & 6976.98 & 421.87 & 2561.46 \\
\hline Year & & &
\end{tabular}


In Table 4, the projected energy consumption of the NZEB, as well as generation by the PV system, energy balance, cumulative energy account and cost of energy are presented, assuming that the interconnection contract begins in November.

Table 4: Monthly energy consumption, generation and cost for NZEB.

\begin{tabular}{|l|r|r|r|r|r|r|}
\hline & $\begin{array}{c}\text { Consumption } \\
\mathrm{kWh}\end{array}$ & $\begin{array}{c}\text { Generation } \\
\mathrm{kWh}\end{array}$ & $\begin{array}{c}\text { Balance } \\
\mathrm{kWh}\end{array}$ & $\begin{array}{c}\text { Cumulative } \\
\mathrm{kWh}\end{array}$ & $\begin{array}{c}\text { Cost } \\
\mathrm{USD}\end{array}$ & $\begin{array}{c}\text { Billing } \\
\mathrm{USD}\end{array}$ \\
\hline Nov & 223.94 & 473.93 & 249.99 & 0.00 & 0.0 & 1.15 \\
\hline Dec & 231.40 & 453.16 & 221.76 & 249.99 & 0.0 & 1.16 \\
\hline Jan & 232.23 & 486.38 & 254.15 & 471.75 & 0.0 & 1.52 \\
\hline Feb & 209.76 & 476.96 & 267.20 & 725.90 & 0.0 & 1.52 \\
\hline Mar & 232.23 & 619.29 & 387.06 & 993.10 & 0.0 & 1.53 \\
\hline Apr & 224.74 & 630.44 & 405.70 & 1380.16 & 0.0 & 1.53 \\
\hline May & 689.34 & 626.66 & -62.68 & 1785.86 & 0.0 & 1.14 \\
\hline Jun & 808.65 & 575.49 & -233.16 & 1723.18 & 0.0 & 1.14 \\
\hline Jul & 1009.24 & 556.51 & -452.73 & 1490.02 & 0.0 & 1.15 \\
\hline Aug & 983.37 & 533.84 & -449.53 & 1037.29 & 0.0 & 1.15 \\
\hline Sep & 807.59 & 540.35 & -267.24 & 587.76 & 0.0 & 1.57 \\
\hline Oct & 642.64 & 542.33 & -100.31 & 320.52 & 0.0 & 1.58 \\
\hline Year & 6295.13 & 6515.34 & 220.21 & 420.83 & 0.0 & 16.13 \\
\hline
\end{tabular}

The savings in billing is $\$ 405.74$ USD with subsidized tariff $1 \mathrm{~F}$; however if the rate were not subsidized, the savings would be $\$ 2543.32$ USD. Investment needed, including insulation, photovoltaic equipment and installation is $\$ 10982.72$ USD.

The economic indicator used is the simple payback time (PBT) calculated as the investment divided by the annual savings, at constant dollars [7].

In these circumstances, the PBT with subsidized rate is 27.07 years, while if it is not subsidized the PBT is 4.07 years.

This shows that the fact that the rate is subsidized, for the economic level to which the study was conducted makes the Net Zero project economically unviable, as PBT is greater than the expected life of the project.

\subsection{Alternative scenario}

If the State, in an effort to encourage the use of renewable sources of energy decided to grant financing like it did in FIPATERM, with credits to five years with zero interest rate, payable via the electricity billing, the monthly payment indicated in table 4 would rise \$183.05 USD; and from year 6 the user would pay as indicated. This alternative scenario would benefit the economic sector of renewable sources of energy: manufacturers, installers, providers of supplies, etc. In addition the economy of the user would be benefited and the State could allocate resources of the subsidy from year 6 to social work and infrastructure. From an environmental point of view, the reduction in $\mathrm{CO}_{2}$ generation in the 
production plant would be 3.71 tons per year, applying a factor of 0.57 tons of $\mathrm{CO}_{2}$ per MWh generated, according to Molina [8], since power generating plants are geothermal.

\section{Conclusions}

The proposal of NZEB house generates $6,515.36 \mathrm{kWh}$ a year, same that are supplied directly to the grid. With subsidized energy costs, and under the consideration that the photovoltaic system has a life at maximum power for 25 years, the investment project to achieve an NZEB is unattractive. If the electricity is paid under unsubsidized cost, the project is economically feasible. While subsidized rates result in economic and social support for the inhabitants of areas with dry warm climate, they constitute an inhibitor of the investment for the promotion and use of renewable energy in the middle class housing sector. On the other hand, if the Federal amounts intended to subsidize electricity rates, are used to finance the acquisition of systems for energy generation from renewable sources, it would represent an opportunity to eliminate subsidies in future years, in such a way that those saved resources can be used for public investment in areas with lag, such as social assistance, and infrastructure for instance. It is necessary to study the economic impacts that would result from providing public resources, currently used to subsidize electric rates in the housing sector, to investment in cogeneration from renewable energy systems instead, as well as the impact that would result in the availability of generation capacity of the CFE plants and its relationship to $\mathrm{CO}_{2}$ emissions.

\section{References}

[1] http://app.cfe.gob.mx/Aplicaciones/CCFE/Tarifas/Tarifas/Tarifas_casa.asp? Tarifa $=$ DACTAR $1 \&$ anio $=2013$

[2] Torcellini, P., Pless, S. \& Deru, M. Zero Energy Buildings: A Critical Look at the Definition. National Renewable Energy Laboratory and Department of Energy. 2006.

[3] Voss, K. et al. From low-energy to net zero-energy buildings: status and perspectives. http://task40.iea-shc.org/publications

[4] Sartori, I., Napolitano, A. \& Voss, K. (2012). Net zero energy buildings: A consistent definition framework. http://task40.iea-shc.org/publications

[5] Docherty, M. \& Szokolay, S. Climate Analysis. The University of Queensland Printery, Australia. 1999.

[6] Diario Oficial de la Federacón. Norma Oficial Mexicana NOM-020-ENER2011, Eficiencia energética en edificaciones.- Envolvente de edificios para uso habitacional. 09-Aug-2011.

[7] Kreider , F., Curtis, P. \& Rabi, A. Heating and Cooling of Buildings: Design for Efficiency. Second Edition. Mc Graw Hill 2002.

[8] Molina, M. Inventario de emisiones de gases de efecto invernadero del Estado de Baja California, 2005. México: Centro Mario Molina. 2007. 